\title{
EDITORIAL
}

\section{The future of allogeneic hematopoietic stem cell transplantation for metastatic renal cell carcinoma in the era of target-specific therapy}

\author{
Bone Marrow Transplantation (2006) 38, 711-714. \\ doi:10.1038/sj.bmt.1705523
}

Metastatic renal cell carcinoma (RCC) is observed in approximately $30 \%$ of patients at presentation and develops in $40 \%$ of patients with localized disease at presentation. ${ }^{1}$ Early-stage RCC can be cured by nephrectomy, but metastatic RCC has a median survival time of only 12-15 months and a 5-year survival rate of less than $5 \% .^{2}$ One of the reasons for this poor outcome is the resistance of metastatic RCC to conventional chemotherapy. Because RCC is well known to possess immunogenic properties, immunotherapy with cytokines such as interferon- $\alpha$ and interleukin-2, either alone or in combination, has been one of the major forms of treatment for metastatic disease. However, the response rate is no more than $20 \%$ and the responses usually are partial and of short duration. Moreover, cytokine treatment is also associated with side effects such as asthenia and depression that significantly affect patients' quality of life. Another immunotherapy approach being studied for the treatment of metastatic $\mathrm{RCC}$ is allogeneic hematopoietic stem cell transplantation as a means to develop immune-mediated graft-versustumor (GVT) effects.

In 1999, Childs et al. ${ }^{3}$ reported the first successful use of non-myeloablative allogeneic transplantation for the treatment of RCC. In 2000, they reported findings from a series of 19 patients with advanced RCC treated with this approach. ${ }^{4}$ All 19 patients had had progressive disease before the transplantation, and prior cytokine therapy had failed to produce a response in 17 patients. Stem cells from human leukocyte antigen (HLA)-matched sibling donors were used for 17 patients, and the other two were given cells from a sibling donor mismatched at a single HLA locus. A reduced-intensity conditioning regimen consisting of fludarabine and cyclophosphamide was used. Cyclosporine was used as prophylaxis for graftversus-host disease (GVHD), and the two patients with the single HLA locus mismatch were also given antithymocyte globulin. All patients experienced sustained engraftment and mixed chimerism; recipient cells predominated among the myeloid cells, and donor cells predominated among the T cells. After the cyclosporine was discontinued, eight patients were given a donor lymphocyte infusion, either to establish complete donor chimerism or to treat progressive disease. The incidence of acute GVHD of grade II or above was $53 \%$ and that of chronic GVHD was $21 \%$. The treatment-related mortality rate was $11 \%$. At a median follow-up time of 402 days, nine patients were still alive; of the 10 patients who died, two died of treatment-related causes and eight of progressive disease. The overall response rate was $53 \%$, with three complete and seven partial responses. Two of the seven patients who experienced a partial response experienced subsequent disease relapse. Responses were seen only among patients with clear-cell disease. The onset of tumor response was delayed by a median of 4 months after transplantation; responses typically appeared after complete donor chimerism had been achieved, after withdrawal of immunosuppressive therapy, or after the development of GVHD. (All of these features are suggestive of the presence of GVT effects.) The development of GVHD was the only factor that predicted response.

The encouraging results observed in this study have led to wider use of non-myeloablative allogeneic stem-cell transplantation as an adoptive immunotherapy strategy for RCC. Since Childs et al. published their findings in 2000, 16 other studies have been reported worldwide $\left(12\right.$ series $^{5-18}$ and four case reports ${ }^{19-22}$ ), for a total of 167 patients. Although the treatment strategies used were similar to that of Childs et al., variations in conditioning regimens, GVHD prophylaxis and engraftment rates were reported. The incidence of GVHD and the treatment-related mortality and response rates of all 17 studies are summarized in Table 1. Briefly, the median incidence of acute GVHD was $50 \%$, the median incidence of chronic GVHD was $30 \%$ and the median treatment-related mortality rate was $14 \%$. The incidence rates concurred with those reported in allogeneic matched related-donor stem-cell transplantation for hematologic malignancies. In the 17 studies, the median response rate (complete and partial responses) was $22 \%$ (range, $0-100 \%$ ). Most of the reported responses suggested the presence of GVT effects based on the temporal relationship of GVHD occurrence or the introduction of donor lymphocyte infusions. The wide range of responses may reflect differences in the patient selection processes at different institutions. In July 2006 , Barkholt et al. ${ }^{23}$ reported the combined results of allogeneic hematopoietic stem-cell transplantation for metastatic RCC on behalf of the French Immunotherapy and Cancer (ITAC) group and the European Blood and Marrow Transplantation solid tumor working party. (Some of the data may have already been reported by the individual institutions.) With a total of 124 patients, the incidence of acute GVHD of grade II or above was $40 \%$ and that of chronic GVHD was $30 \%$. The treatment-related mortality rate was $16 \%$ and the response rate was $23 \%$. These findings were almost identical to those in the 17 studies listed here. 
Table 1 Summary of the incidence of acute and chronic GVHD, and rates of treatment-related mortality and response in studies of stem cell transplantation for metastatic RCC

\begin{tabular}{|c|c|c|c|c|c|}
\hline Study & $\begin{array}{c}\text { Number of } \\
\text { patients }\end{array}$ & $\begin{array}{c}\text { Acute GVHD } \\
\text { number }(\%)\end{array}$ & $\begin{array}{c}\text { Chronic GVHD } \\
\text { number }(\%)\end{array}$ & $\begin{array}{c}\text { TRM rate } \\
\text { number }(\%)\end{array}$ & $\begin{array}{c}\text { Response } \\
\text { rate number }(\%)\end{array}$ \\
\hline Childs et al..$^{3,4}$ & 19 & $10(53)$ & $4(21)$ & $2(11)$ & $10(53)$ \\
\hline Pedrazzoli et al. ${ }^{5}$ & 8 & 0 & 0 & $2(25)$ & 0 \\
\hline Bregni et al. ${ }^{6}$ & 7 & $6(86)$ & $5(71)$ & $1(14)$ & $4(57)$ \\
\hline Hentschke et al. ${ }^{7}$ & 10 & $5(50)$ & $3(30)$ & $3(30)$ & $3(30)$ \\
\hline Baron et al. ${ }^{8}$ & 7 & $3(43)$ & $1(14)$ & 0 & $1(14)$ \\
\hline Aoyama et al. ${ }^{19}$ & 2 & $1(50)$ & 0 & 0 & $1(50)$ \\
\hline Ueno et al. ${ }^{9}$ & 15 & $7(47)$ & $4(27)$ & $5(33)$ & $3(20)$ \\
\hline Blaise et al. ${ }^{10}$ & 25 & $4(17)$ & $7(28)$ & No data & $2(8)$ \\
\hline Bornhauser et al. ${ }^{20}$ & 1 & $1(100)$ & $1(100)$ & $1(100)$ & $1(100)$ \\
\hline Takami et al. ${ }^{21}$ & 3 & $2(67)$ & $2(67)$ & $2(67)$ & $2(67)$ \\
\hline Nakagawa et al..$^{11}$ & 9 & $3(33)$ & $4(44)$ & 0 & $1(11)$ \\
\hline Massenkeil et al. ${ }^{12}$ & 7 & $2(29)$ & $4(57)$ & $1(14)$ & $2(29)$ \\
\hline Tykodi et $a l .^{13}$ & 8 & $4(50)$ & $4(50)$ & $1(13)$ & $1(13)$ \\
\hline Secondino et al..$^{22}$ & 1 & $1(100)$ & $1(100)$ & $1(100)$ & $1(100)$ \\
\hline Rini et al. ${ }^{14,15}$; Artz et al. ${ }^{16}$ & 18 & $3(17)$ & $7(39)$ & $6(33)$ & $4(22)$ \\
\hline Rzepecki et al. ${ }^{17}$ & 5 & $3(60)$ & 0 & 0 & 0 \\
\hline Rini et al. $(\mathrm{CALGB})^{18}$ & 22 & $11(50)$ & $5(23)$ & $2(9)$ & 0 \\
\hline
\end{tabular}

Abbreviations: GVHD = graft-versus-host disease; RCC = renal cell carcinoma; TRM = treatment-related mortality.

In this issue of Bone Marrow Transplantation, Takami et $a l .^{24}$ report a single case of allogeneic hematopoietic unrelated cord blood transplantation for metastatic RCC. One might wonder what makes a single case report worth an editorial discussion. First of all, this is the first case of the use of hematopoietic unrelated cord blood as the source of stem cells. In all previous 17 studies, all donor stem cells were from adults, either related siblings or unrelated volunteers. Second, this is also the first case of successful engraftment using hematopoietic unrelated cord blood in allogeneic transplantation for metastatic RCC. At MD Anderson Cancer Center, we have attempted one case of allogeneic hematopoietic unrelated cord blood transplantation for this purpose, but ended with graft failure. Unfortunately, the patient died soon after graft failure and thus was unable to attempt a second cord blood transplantation. Third, in Takami et al.'s case, the observation of a partial response (at day 60) after the appearance of acute GVHD (at day 47) and the presence of stable disease (from 18 to 26 months after the transplant) after discontinuation of immunosuppression (at 11 months after the transplant) did suggest the possibility of GVT effects. Finally, as transplant physicians, it is our responsibility to encourage continuous scientific and clinical research to improve transplantation knowledge and technology. Treatment strategies for metastatic RCC have undergone a major change recently with the introduction of target-specific therapy. Two oral tyrosine kinase receptor inhibitors (sunitinib, which targets the vascular endothelial growth factor receptor and platelet-derived growth factor receptor, and sorafenib, which targets the Ras/Raf pathway) have shown activity in metastatic RCC. ${ }^{25-27}$ Although clinically significant responses have been observed, most patients experience only stabilization of disease. Further, compared with interferon- $\alpha$, interleukin- 2 or allogeneic transplantation, this target-specific therapy has not led to durable complete responses. However, the simple mode of administration and the relatively low treatment-related morbidity and mortality rates make this target-specific therapy a much more attractive choice than allogeneic hematopoietic stem cell transplantation. Currently, these new agents are becoming the front-line treatment for metastatic RCC, but their full impact still awaits long-term results from patients given these agents as first-line therapy and as salvage therapy.

In the present era of target-specific therapy, interest in the complex procedure of allogeneic transplantation tends to fall off. However, we must not forget both direct and indirect evidence of GVT effects that have been demonstrated in various studies. ${ }^{3-23}$ Only ongoing research can confirm these results and clarify the true nature of the GVT effects. Improving the long-term outcome of patients who undergo allogeneic transplantation for RCC requires addressing several issues. The first of these issues, identifying the specific tumor antigens involved in the GVT effect in metastatic RCC, will allow the GVT effect to be separated from the unwanted effect of GVHD. This is an important goal in allogeneic transplantation, because GVHD is still a major cause of morbidity and mortality even when non-myeloablative conditioning regimens are used. Identification of the specific tumor antigens will also allow the development of tumor-specific cytotoxic $\mathrm{T}$ cells. The second issue is identifying the optimal conditioning regimen and GVHD prophylaxis to be used with allogeneic transplantation for RCC. The ideal conditioning regimen should be immunosuppressive enough to achieve rapid donor chimerism, but not so intense or myelosuppressive that it causes significant treatment-related morbidity and mortality. Third, most donor cells used in allogeneic transplantation for RCC currently are from matched or single-HLA-locus-mismatched related donors. However, because suitable donors can be found only $20-30 \%$ of the time, other possible sources of stem cells, such as matched unrelated donors, umbilical cord blood or haploidentical 
donors, should be investigated. A fourth important issue is how to select the candidates with the best chance of response to this type of treatment. Experience has shown that patient selection affects treatment-related mortality. Most of the patients in the trials conducted to date have had high tumor burdens, progressive disease after multiple prior treatments or rapidly progressive disease, all of which are associated with poor prognosis. Further, many of these patients have had borderline organ function, which put them at high risk of treatment-related complications. Thus, the heterogeneous responses observed across the different clinical trials are hardly surprising. The success of allogeneic transplantation as adoptive immunotherapy depends on the ability of donor $\mathrm{T}$ cells to induce a GVT effect. The donor $\mathrm{T}$ cells need time to become fully engrafted and mature enough to function, which is why most of the GVT effects observed in the 17 reported studies did not appear until 4-6 months after the transplant. Patients with rapidly progressive disease or high tumor burden may not survive long enough to experience a GVT effect, and thus careful selection of patients for this kind of treatment is needed not only to ensure a successful transplant but also to provide the most benefit to the patients. Finally, identifying an HLA-matched or HLAcompatible donor and obtaining third-party financial approval for allogeneic transplantation can take 2-3 months. Thus, if allogeneic transplantation is to be considered as a viable treatment option for patients with metastatic RCC, consultation with a transplantation team is advisable as early as possible in the course of treatment. Therefore, close collaborations between specialists in renal carcinoma and stem-cell transplant teams are extremely important.

In summary, allogeneic hematopoietic stem cell transplantation for metastatic RCC deserves further exploration as a treatment option in the era of target-specific therapy. The observation in several studies of a GVT effect after allogeneic transplantation for metastatic RCC underscores the necessity of a continuing commitment to research in this field, with the goals of clarifying the true nature of the GVT effect, improving the technology of allogeneic transplantation and ultimately improving the outcome of patients with metastatic RCC.

NT Ueno ${ }^{1,2}$ and YC Cheng ${ }^{3}$

${ }^{1}$ Department of Stem Cell Transplantation and Cellular Therapy, The University of Texas MD Anderson Cancer Center, Houston, TX, USA; ${ }^{2}$ Department of Breast Medical Oncology, The University of Texas MD Anderson Cancer Center, Houston, TX, USA and

${ }^{3}$ Department of Medicine, Division of Neoplastic Diseases and Related Disorders, Medical College of Wisconsin, Milwaukee, WI, USA

E-mail:nueno@mdanderson.org

\section{References}

1 Linehan WM, Zbar B, Bates SE, Zelefsky MJ, Yang JC. Cancer of the kidney and ureter. In: DeVita VT, Hellman S, Rosenberg SA (eds). Cancer: Principles and Practice of Oncology. J.B. Lippincott Co.: Philadelphia, 2001, pp 1362-1384.
2 Motzer RJ, Bander NH, Nanus DM. Renal-cell carcinoma. $N$ Engl J Med 1996; 335: 865-875.

3 Childs RW, Clave E, Tisdale J, Plante M, Hensel N, Barrett J. Successful treatment of metastatic renal cell carcinoma with a nonmyeloablative allogeneic peripheral-blood progenitor-cell transplant: evidence for a graft-versus-tumor effect. J Clin Oncol 1999; 17: 2044-2049.

4 Childs R, Chernoff A, Contentin N, Bahceci E, Schrump D, Leitman $\mathrm{S}$ et al. Regression of metastatic renal-cell carcinoma after nonmyeloablative allogeneic peripheral-blood stem-cell transplantation. $N$ Engl J Med 2000; 343: 750-758.

5 Pedrazzoli P, Da Prada GA, Giorgiani G, Schiavo R, Zambelli A, Giraldi E et al. Allogeneic blood stem cell transplantation after a reduced-intensity, preparative regimen: a pilot study in patients with refractory malignancies. Cancer 2002; 94: 2409-2415.

6 Bregni M, Dodero A, Peccatori J, Pescarollo A, Bernardi M, Sassi I et al. Nonmyeloablative conditioning followed by hematopoietic cell allografting and donor lymphocyte infusions for patients with metastatic renal and breast cancer. Blood 2002; 99: 4234-4236.

7 Hentschke P, Barkholt L, Uzunel M, Mattson J, Wersall P, Pisa $\mathrm{P}$ et al. Low-intensity conditioning and hematopoietic stem cell transplantation in patients with renal and colon carcinoma. Bone Marrow Transplant 2003; 31: 253-261.

8 Baron F, Frere P, Baudoux E, Sautois B, Fillet G, Bequin Y. Non-myeloablative stem cell transplantation with low-dose total body irradiation and fludarabine for metastatic renal cell carcinoma. Haematologica 2003; 88: 479-480.

9 Ueno NT, Cheng YC, Rondon G, Tannir NM, Gajewski JL, Couriel DR et al. Rapid induction of complete donor chimerism by the use of a reduced-intensity conditioning regimen composed of fludarabine and melphalan in allogeneic stem cell transplantation for metastatic solid tumors. Blood 2003; 102: 3829-3836.

10 Blaise D, Bay JO, Faucher C, Michallet M, Boiron JM, Choufi $\mathrm{B}$ et al. Reduced-intensity preparative regimen and allogeneic stem cell transplantation for advanced solid tumors. Blood 2004; 103: 435-441.

11 Nakagawa T, Kami M, Hori A, Kim SW, Murashige N, Hamaki $\mathrm{T}$ et al. Allogeneic hematopoietic stem cell transplantation with a reduced-intensity conditioning regimen for treatment of metastatic renal cell carcinoma: single institution experience with a minimum 1-year follow-up. Exp Hematol 2004; 32: 599-606.

12 Massenkeil G, Roigas J, Nagy M, Wille A, Stroszczynski C, Mapara MY et al. Nonmyeloablative stem cell transplantation in metastatic renal cell carcinoma: delayed graft-versustumor effect is associated with chimerism conversion but transplantation has high toxicity. Bone Marrow Transplant 2004; 34: 309-316.

13 Tykodi SS, Warren EH, Thompson JA, Riddell SR, Childs $\mathrm{RW}$, Otterud BE et al. Allogeneic hematopoietic cell transplantation for metastatic renal cell carcinoma after nonmyeloablative conditioning: toxicity, clinical response, and immunological response to minor histocompatibility antigens. Clin Cancer Res 2004; 10: 7799-7811.

14 Rini BI, Zimmerman TM, Gajewski TF, Stadler WM, Vogelzang NJ. Allogeneic peripheral blood stem cell transplantation for metastatic renal cell carcinoma. J Urol 2001; 165: 1208-1209.

15 Rini BI, Zimmerman T, Stadler WM, Gajewski TF, Vogelzang NJ. Allogeneic stem-cell transplantation of renal cell cancer after nonmyeloablative chemotherapy: feasibility, engraftment, and clinical results. J Clin Oncol 2002; 20: 2017-2024.

16 Artz AS, Van Besien K, Zimmerman T, Gajewski TF, Rini BI, $\mathrm{Hu} \mathrm{HS}$ et al. Long-term follow-up of nonmyeloablative 
allogeneic stem cell transplantation for renal cell carcinoma: The University of Chicago Experience. Bone Marrow Transplant 2005; 35: 253-260.

17 Rzepecki P, Zolnierek J, Sarosiek T, Langiewicz P, Szczylik C. Allogeneic non-myeloablative hematopoietic stem cell transplantation for treatment of metastatic renal cell carcinoma single center experience. Neoplasma 2005; 52: 238-242.

18 Rini BI, Halabi S, Barrier R, Margolin KA, Avigan D, Logan $\mathrm{T}$ et al. Adoptive immunotherapy by allogeneic stem cell transplantation for metastatic renal cell carcinoma: a CALGB intergroup phase II study. Biol Blood Marrow Transplant 2006; 12: $778-785$.

19 Aoyama Y, Nakamae H, Yamamura R, Makita K, Shima E, Ohta $\mathrm{K}$ et al. Reduced-intensity stem cell transplantation in two cases of metastatic renal cell carcinoma. Int J Urol 2003; 10: 610-614; discussion 615 .

20 Bornhauser M, Klenk U, Rollig C, Haack M, Babatz J, Koch $\mathrm{O}$ et al. Mixed response after allogeneic haemopoietic-cell transplantation for metastatic renal-cell carcinoma. Lancet Oncol 2004; 5: 191-192.

21 Takami A, Asakura H, Koshida K, Namiki M, Nakao S. Reduced-intensity allogeneic stem cell transplantation for renal cell carcinoma: in vivo evidence of a graft-versus-tumor effect. Haematologica 2004; 89: 375-376.

22 Secondino S, Pedrazzoli P, Giannetta L, Schiavetto I, Vanzulli A, Siena S. Evidence of graft-versus-tumour effect following allogeneic haematopoietic stem cell transplantation in renal cancer other than clear cell type. Bone Marrow Transplant 2004; 34: 917-918.

23 Barkholt L, Bregni M, Remberger M, Blaise D, Peccatori J, Massenkeil $\mathrm{G}$ et al. Allogeneic haematopoietic stem cell transplantation for metastatic renal cell carcinoma in Europe. Ann Oncol 2006; 17: 1134-1140.

24 Takami A, Takamatsu H, Yamazaki H, Ishiyama K, Okumura $\mathrm{H}$, Ohata $\mathrm{K}$ et al. Reduced-intensity unrelated cord blood transplantation for treatment of metastatic renal cell carcinoma: first evidence of cord-blood-versus-solid-tumor effect. Bone Marrow Transplant 2006; 38: 729-732.

25 Escudier B, Szczylik C, Eisen T, Stadler WM, Schwartz B, Shan $\mathrm{M}$ et al. Randomized phase III trial of the Raf kinase and VEGFR inhibitor sorafenib (BAY 43-9006) in patients with advanced renal cell carcinoma (RCC). Proc ASCO 2005; 23: 380s (abstract).

26 Ratain MJ, Eisen T, Stadler WM, Flaherty KT, Kaye SB, Rosner GL et al. Phase II placebo-controlled randomized discontinuation trial of sorafenib in patients with metastatic renal cell carcinoma. J Clin Oncol 2006; 24: $2505-2512$.

27 Motzer RJ, Michaelson MD, Redman BG, Hudes GR, Wilding G, Figlin RA et al. Activity of SU11248, a multitargeted inhibitor of vascular endothelial growth factor receptor and platelet-derived growth factor receptor, in patients with metastatic renal cell carcinoma. J Clin Oncol 2006; 24: 16-24. 